\title{
Pengaruh Pelatihan Dan Disiplin Kerja Terhadap Kinerja Karyawan Pada PT. Bank Negara Indonesia Di BSD Tangerang
}

\author{
${ }^{1} N$. Lilis Suryani, Kiki Zakiah \\ Dosen Fakultas Ekonomi Universitas Pamulang \\ ${ }^{1}$ Email : dosen000437@unpam.ac.id
}

\begin{abstract}
ABSTRAK
Tujuan pada penelitian ini adalah untuk mengetahui pengaruh pelatihan dan disiplin kerja terhadap kinerja karyawan pada PT. Bank Negara Indonesia (BNI).

Metode yang digunakan adalah metode deskriptif dengan pendekatan asosiatif. Teknik sampling yang digunakan adalah proporsional random sampling menggunakan metode teknik sampling jenuh dengan sampel sebanyak 50 responden. Analisis data menggunakan analisis regresi, analisis koefisien korelasi, analisis koefisien determinasi dan uji hipotesis

Hasil penelitian ini adalah pelatihan berpengaruh positif dan signifikan terhadap kinerja karyawan sebesar 44,1\%. Uji hipotesis secara parsial diperoleh $\mathrm{t}$ hitung $>\mathrm{t}$ tabel atau $(6,152>2,011)$, sehingga $\mathrm{H}_{0}$ ditolak dan $\mathrm{H}_{1}$ diterima artinya terdapat pengaruh positif dan signifikan antara pelatihan terhadap kinerja karyawan pada PT. Bank Negara Indonesia (BNI). Disiplin kerja berpengaruh positif dan signifikan terhadap kinerja karyawan sebesar $47,0 \%$. Uji hipotesis secara parsial diperoleh $\mathrm{t}$ hitung $>\mathrm{t}$ tabel atau $(6,520>2,011)$ sehingga $\mathrm{H}_{0}$ ditolak dan $\mathrm{H}_{2}$ diterima artinya terdapat pengaruh positif dan signifikan antara disiplin kerja terhadap kinerja karyawan pada PT. Bank Negara Indonesia (BNI). Uji hipotesis simultan pelatihan dan disiplin kerja berpengaruh positif dan signifikan terhadap kinerja karyawan dengan koefisien determinasi sebesar 57,7\%, sedangkan sisanya sebesar 42,3\% dipengaruhi faktor lain. Uji hipotesis diperoleh nilai $\mathrm{F}$ hitung $>\mathrm{F}$ tabel atau $(32,019>2,800)$, dengan demikian Ho ditolak dan $\mathrm{H}_{3}$ diterima. Artinya terdapat pengaruh positif dan signifikan secara simultan antara pelatihan dan disiplin kerja terhadap kinerja karyawan pada PT. Bank Negara Indonesia.
\end{abstract}

Kata Kunci : Pelatihan, Disiplin Kerja, Kinerja Karyawan. 


\section{PENDAHULUAN}

\section{A. Latar Belakang Masalah}

Manajemen sumber daya manusia diperlukan untuk meningkatkan efektivitas sumber daya manusia dalam organisasi. Tujuannya adalah memberikan kepada organisasi satuan kerja yang efektif. Untuk mencapai tujuan ini, studi tentang manajemen personalia akan menunjukkan bagaimana seharusnya perusahaan mendapatkan, mengembangkan, menggunakan, mengevaluasi dan memelihara karyawan dalam jumlah (kuantitas) dan tipe (kualitas).

Untuk meningkatkan kinerja karyawan pada Bank BNI BSD, satu langkah yang penting ialah dengan memberikan program pelatihan kepada karyawan Bank BNI BSD, karena pelatihan merupakan salah satu metode yang tepat untuk meningkatkan kemampuan karyawan. Berdasarkan observasi sejumlah pegawai yang mengikuti pendidikan dan pelatihan di Bank BNI BSD tidak semuanya diikuti oleh karyawan, dimana untuk pendidikan dan pelatihan karyawan tahap awal klasikal tahun 2015 diikuti oleh 50 karyawan, tahun 2016 diikuti 43 karyawan, dan tahun 2017 hanya diikuti sebanyak 40 karyawan. Selanjutnya untuk pelatihan Manajemen Resiko pada tahun 2015 diikuti oleh 50 karyawan, tahun 2016 diikuti sebanyak 40 karyawan, dan tahun 2017 hanya diikuti 37 karyawan. Untuk Pelatihan Grafonomi, verifikasi dokumen dan pemeriksaan uang bagi calon asisten pelayanan uang tunai pada tahun 2015 diikuti 50 karyawan, tahun 2016 diikuti 48 karyawan dan tahun 2017 hanya diikuti 44 karyawan. Kurangnya karyawan yang mengikuti pelatian menyebabkan penurunan kinerja karyawan di Bank BNI BSD. Karyawan dituntut utuk memiliki kemampuan dan keahlian di bidang perbankan, hal tersebut untuk meningkatkan kinerja karyawan di Bank BNI BSD.

Disiplin merupakan fungsi operatif dari Manajemen Sumber Daya Manusia yang terpenting, karena semakin baik disiplin karyawan semakin tinggi prestasi kerja yang dapat dicapainya. Tanpa disiplin yang baik, sulit bagi organisasi mencapai hasil yang optimal. Penerapan disiplin kerja dilingkungan kerja, memang awalnya akan dirasakan berat oleh para pegawai, tetapi apabila terus menerus diberlakukan akan menjadi kebiasaan, dan disiplin tidak akan menjadi beban berat bagi para pegawai. Disiplin ini perlu diterapkan dilingkungan kerja karena disiplin tidak lahir begitu saja, tetapi perlu adanya pembinaan - pembinaan dalam menegakkan disiplin kerja ini.

Berdasarkan hasil observasi disiplin kerja karyawan bank BNI BSD secara keseluruhan masih kurang. Hal ini dikarenakan masih terdapat beberapa indikator mengenai disiplin kerja mendapatkan jawaban yang cenderung negatif sebesar $61,1 \%$ dari total 12 responden yang menjawab, seperti karyawan yang datang terlambat dan karyawan yang kurang berhati-hati dalam 
menggunakan peralatan yang disediakan oleh bank BNI BSD untuk menunjang pekerjaan mereka. Kurangnya disiplin kerja pada diri karyawan menyebabkan menurunnya kinerja yang dihasilkan oleh karyawan di bank BNI BSD dan jika hal ini terus terjadi maka kinerja bank BNI BSD akan menurun. Karyawan tidak hanya dituntut untuk memiliki kualitas kerja tetapi juga dituntut untuk memiliki sikap dan moral yang baik. Maka dari disiplin kerja sangat diperlukan untuk meningkatkan kinerja karyawan dan meminimalisir ketidakhadiran karyawan saat bekerja.

Berdasarkan observasi kinerja karyawan secara keseluruhan belum sesuai dengan yang diharapkan. Hal ini dapat dilihat banyaknya karyawan yang memberikan respon tidak sebesar $63,9 \%$ dari total 12 responden yang menjawab terhadap pernyataan dikuesioner. Berdasarkan data tersebut, dapat terlihat karyawan Bank BNI BSD keberatan apabila bekerja melebihi jam kerja mereka, karyawan masih menunda-nunda pekerjaan sehingga pekerjaan tidak dapat diselesaikan dengan tepat waktu. Hal ini akan berdampak terhadap kinerja yang dihasilkan oleh karyawan.

Sesuai dengan UU No.17 Tahun 1968 sebagai bank umum dengan nama Bank Negara Indonesia 1946, Bank Negara Indonesia (BNI) merupakan perusahan yang bergerak dibidang jasa perbankan. BNI bertugas memperbaiki ekonomi rakyat dan berpartisipasi dalam pembangunan ekonomi nasional. Segmentasi nasabah juga telah dibidik BNI sejak awal dirintisnya bank yang melayani khusus nasabah wanita yaitu Bank Sarinah dimana seluruh petugas bank adalah perempuan dan Bank Bocah yang memberikan edukasi kepada anak - anak agar memiliki kebiasaan menabung sejak dini. Pelayanan Bank Bocah dilakukan juga oleh anak-anak.

Globalisasi juga menuntut industri perbankan untuk selalu meningkatkan kemampuan dalam memberikan solusi perbankan kepada seluruh nasabah. Secara historis BNI focus pada corporate banking yang didukung dengan infrastruktur retail banking yang kuat. Kini BNI terus berupaya meningkatkan kapitalisasi keduanya menjadi keunggulan BNI. Dengan sejarah yang kaya, kondisi financial yang kuat, sumber daya manusia yang unggul dan teknologi yang andal, BNI yakin telah berada di jalur yang tepat untuk menjadi bank nasional yang berkemampuan global.

\section{B. Identifikasi Masalah}

1. Karyawan yang memiliki sikap ingin belajar dalam pelatihan di PT Bank BNI BSD masih rendah.

2. Masih banyak karyawan yang kurang memiliki pengetahuan di bidang masing-masing.

3. Karyawan yang tidak disiplin dalam bekerja akan menerima sangsi hukuman.

4. Masih rendahnya ketegasan karyawan untuk menjalankan tugasnya. 
5. Masih banyak kualitas kerja karyawan yang harus di tingkatkan.

6. Masih banyak karyawan yang kurang efektiv dalam menjalankan tanggung jawabnya.

\section{Rumusan Masalah}

1. Bagaimana pengaruh pelatihan terhadap kinerja karyawan di PT Bank BNI ?
2. Bagaimana pengaruh disiplin Kerja terhadap kinerja karyawan di PT Bank BNI?

3. Seberapa besar pengaruh pelatihan dan disiplin kerja terhadap kinerja karyawan secara simultan?

\section{Kerangka Berpikir}

\section{Pengaruh Pelatihan dan Disiplin Kerja terhadap Kinerja Karyawan} Pada PT. Bank Negara Indonesia

\section{Pelatihan (X1)}

\section{Indikator}

1. Sikap

2. Pengetahuan

3. Keterampilan

Sumber : Mustofa Kamil (2015:11)

\begin{tabular}{|l|} 
Disiplin Kerja (X2) \\
Indikator \\
1. Tujuan dan kemampuan \\
2. Teladan pimpinan \\
3. Balas jasa \\
4. Keadilan \\
5. Waskat \\
6. Sanksi hukuman \\
7. Ketegasan \\
Sumber : Hasibuan (2017:194)
\end{tabular}

Gambar 1.1

Kerangka Berfikir 


\section{E. Hipotesis}

$\mathrm{H}_{1}=$ Terdapat pengaruh positif dan signifikan pelatihan $\left(\mathrm{X}_{1}\right)$ terhadap kinerja karyawan (Y).

$\mathrm{H}_{2}=$ Terdapat pengaruh positif dan signifikan disiplin kerja $\left(\mathrm{X}_{2}\right)$ terhadap kinerja karyawan $(\mathrm{Y})$.

$\mathrm{H}_{3}=$ Terdapat pengaruh positif dan signifikan pelatihan $\left(\mathrm{X}_{1}\right)$ dan disiplin kerja $\left(\mathrm{X}_{2}\right)$ terhadap kinerja karyawan (Y) secara simultan.

\section{TINJAUAN PUSTAKA}

\section{A. Pelatihan}

Chan (2010) dalam Donni (2014:175) menyatakan bahwa pelatihan merupakan pelajaran yang disediakan dalam rangka meningkatkan kinerja terkait dengan pekerjaan saat ini. Pelatihan memungkinkan pegawai memperoleh kemampuan tambahan sehingga ia dapat mengemban tugas atau pekerjaan aktual yang dihadapi secara lebih baik, lebih cepat, lebih mudah, dengan kualitas pekerjaan yang lebih tinggi dan menghasilkan kinerja dan produktifitas kerja yang lebih baik (Donni, 2014: 176).

Menurut Edwin B. Flippo dalam Mustofa Kamil (2010:3) mengemukakan bahwa pelatihan adalah tindakan meningkatkan pengetahuan dan keterampilan seseorang pegawai untuk melaksanakan pekerjaan tertentu. Menurut Henry Simamora (2014:273) menyatakan bahwa Pelatihan merupakan proses pembelajaran yang melibatkan perolehan keahlian, konsep,peraturan, atau sikap untuk meningkatkan kinerja karyawan.

Menurut T. Hani Handoko (2014:104) menyebutkan bahwa pelatihan (training) dimaksudkan untuk memperbaiki penguasaan berbagai keterampilan dan teknik pelaksanaan kerja tertentu, terinci dan rutin. Latihan menyiapkan para karyawan untuk melakukan pekerjaan-pekerjaan sekarang. Menurut Gary Dessler dalam Akhmad Subekhi dan Mohammad Jauhar (2012:70) menyatakan bahwa Pelatihan sebagai proses mengajarkan karyawan baru atau yang ada sekarang, keterampilan dasar yang mereka butuhkan untuk menjalankan pekerjaan mereka. Maka dapat disimpulkan bahwa yang dimaksud dengan pelatihan adalah sebuah upaya yang sitematis dan terencana untuk mengubah atau mengembangkan pengetahuan, keterampilan, sikap baru yang sesuai dengan kebutuhan organisasi.

\section{B. Disiplin Kerja}

Disiplin kerja merupakan suatu proses perkembangan konstruktif bagi pegawai yang berkepentingan karena disiplin kerja ditunjukan pada tindakan bukan orangnya. Disiplin juga sebagai proses latihan pada pegawai agar para pegawai dapat mengembangkan kontrol diri dan agar dapat menjadi lebih efektif dalam bekerja. Menurut Rivai \& Sagala (2013:825) disiplin kerja adalah suatu alat yang digunakan para manajer untuk berkomunikasi dengan karyawan agar mereka bersedia untuk mengubah suatu 
perilaku dan untuk meningkatkan kesadaran juga kesediaan seseorang agar menaati semua peraturan dan norma sosial yang berlaku di suatu perusahaan.

Sejalan dengan Rivai \& Sagala, bagi Sintaasih \& Wiratama (2013:129), disiplin kerja adalah merupakan tindakan manajemen untuk mendorong kesadaran dan kesediaan para anggotanya untuk mentaati semua peraturan yang telah ditentukan oleh organisasi atau perusahaan dan norma-norma sosial yang berlaku secara sukarela. Disiplin kerja merupakan suatu proses perkembangan konstruktif bagi pegawai yang berkepentingan karena disiplin kerja ditunjukan pada tindakan bukan orangnya. Disiplin juga sebagai proses latihan pada pegawai agar para pegawai dapat mengembangkan kontrol diri dan agar dapat menjadi lebih efektif dalam bekerja.

Dengan memiliki pengetahuan dan ketrampilan itu pegawai diharapkan mengetahui, memahami, melaksanakan dan mematuhi segala aturan dan norma-norma dalam lingkungan kerja sebagai sistem organisasi pegawai negeri serta metodemetode tertentu dalam menyelesaikan sebuah pekerjaan atau tugas-tugasnya sehari-hari dengan baik yang akhirnya dapat memenuhi tujuan organisasi yang diharapkan. Menurut Hasibuan (2013: 193) mengemukakan bahwa kedisiplinan adalah kesadaran dan kesediaan seseorang mentaati semua peraturan perusahaan dan normanorma sosial yang berlaku.
Kesadaran adalah sikap seseorang yang secara sukarela menaati semua peraturan dan sadar akan tugas dan tanggung jawabnya. Jadi, dia akan mematuhi atau mengerjakan semua tugasnya dengan baik, bukan atas paksaan.

Dengan paparan tersebut disiplin kerja memang dibutuhkan untuk suatu perusahaan dalam kaitannya untuk mempermudah dan melancarkan perusahaan dalam mencapai tujuannya, karena disiplin kerja yang tertanam pada setiap karyawan akan memberikan kesediaan mereka dalam mematuhi dan menjalankan aturan yang telah di tetapkan demi memajukan perusahaan.

\section{Kinerja}

Suatu organisasi, baik itu pemerintah maupun swasta, selalu digerakan oleh sekelompok orang yang berperan aktif untuk mencapai tujuan yang ingin dicapai dari organisasi tersebut. Tujuan organisasi tentunya tidak akan tercapai jika kinerja anggota atau pegawainya tidak maksimal. Menurut Mangkunegara (2013) dalam Pasolong (2010:176) kinerja merupakan hasil kerja secara kualitas dan kuantitas yang dicapai oleh seseorang dalam melaksanakan fungsinya sesuai dengan tanggungjawab yang diberikan kepadanya. Tidak jauh berbeda, Siagian (2016) mendefinisikan kinerja sebagai suatu keseluruhan kemampuan seseorang untuk bekerja sedemikian rupa sehingga mencapai tujuan kerja secara optimal dan berbagai sasaran yang telah diciptakan dengan 
pengorbanan yang secara rasio lebih kecil dibandingkan dengan hasil yang dicapai.

\section{Prawirosentono}

dalam

Pasolong (2014) lebih cenderung menggunakan kata performance dalam menyebut kata kinerja. Menurutnya performance atau kinerja adalah hasil yang dapat dicapai oleh seseorang atau sekelompok orang dalam suatu organisasi, sesuai dengan tanggungjawab masing-masing dalam rangka mencapai tujuan organisasi bersangkutan secara legal, tidak melanggar hukum dan sesuai dengan moral maupun etika. Berbagai pendapat diatas dapat menggambarkan bahwa kinerja pegawai dan kinerja organisasi memiliki keterkaitan yang sangat erat, tercapainya tujuan organisasi tidak bisa dilepaskan dari sumber daya yang dimiliki oleh organisasi yang digerakan atau dijalankan pegawai yang berperan aktif sebagai pelaku dalam upaya mencapai tujuan organisasi.

\section{METODE PENELITIAN}

Penelitian ini dilaksanakan di PT Bank Negara Indonesia KCU BSD di alamat. Jl. MH. Thamrin BSD ruko Blok L-24 Sektor 7 Tangerang Selatan Banten. Jenis penelitian ini adalah asosiatif, populasi dalam penelitian ini adalah karyawan PT. Bank Negara Indonesia (BNI) di BSD Tangerang yang berjumlah 50 karyawan dengan menggunakan metode sampel jenuh berdasarkan pada tempat penelitian yang telah ditetapkan, maka sampel yang dijadikan objek dalam penelitian ini adalah seluruh karyawan yang bekerja di PT Bank BNI BSD berjumlah 50 orang, termasuk dalam manajer dan karyawan secara keseluruhan.

Analisis data menggunakan uji validitas, reliabilitas, uji asumsi klasik, uji normalitas, uji auto korelasi, uji multikolinieritas, uji heteroskedastisitas, persamaan regresi berganda, uji koefisien korelasi, uji dterminasi dan uji hipotesis.

\section{HASIL PENELITIAN}

Keadaan atau kriteria obyek yang diteliti berdasar pada variabel Pelatihan (X1).

Pelatihan merupakan suatu proses pendidikan jangka pendek yang mempergunakan prosedur sistematis dan terorganisir dimana pegawai non-managerial mempelajari pengetahuan dan keterampilan teknis dalam tujuan terbatas. Dengan demikian, kunci untuk memahami proses pelatihan bergantung pada pengetahuan dan keterampilan teknis.

Hal ini dibuktikan dengan melihat secara keseluruhan untuk kuesioner variabel pelatihan (X1) diperoleh rata-rata score 3.91 dengan kriteria baik. Dari keempat indikator tersebut yang mendapatkan ratting score yang paling rendah adalah pada pernyataan daya pikir dan ide karyawan yang baik, sangat dibutuhkan oleh perusahaan dimana hanya mencapai score 3,80 termasuk dalam kategori baik.

\section{Keadaan atau kriteria obyek yang diteliti berdasar pada variabel disiplin kerja (X2).}

Kedisiplinan karyawan dalam perusahaan mempunyai arti dan makna yang sangat luas untuk memajukan perusahaan melalui 
sikap, prilaku dan perbuatan sesuai dengan peraturan dari perusahaan yang telah ditetapkan baik secara tertulis maupun tidak, oleh karenanya salah satu faktor yang menjadi pertimbangan manajer dalam meningkatkan kinerja adalah disiplin kerja karyawan.

Hal ini dibuktikan dengan melihat secara keseluruhan untuk kuesioner variabel disiplin kerja (X2) diperoleh rata-rata score 3.88 dengan kriteria baik. Dari kelima indikator tersebut yang mendapatkan ratting score yang paling rendah adalah pada pernyataan karyawan yang bekerja secara efektif dan professional akan menghasilkan pekerjaan yang memuaskan dimana hanya mencapai rata-rata score 3,68 termasuk dalam kategori baik.

\section{Keadaan atau kriteria obyek yang diteliti berdasar pada variabel kinerja karyawan (Y).}

Kinerja seorang karyawan merupakan hal yang bersifat individual, karena setiap karyawan mempunyai tingkat kemampuan yang berbeda-beda dalam mengerjakan tugasnya. Pihak manajemen dapat mengukur karyawan atas unjuk kerjanya berdasarkan kinerja masingmasing karyawan. Kinerja adalah sebuah aksi, bukan kejadian. Aksi kinerja itu sendiri terdiri dari banyak komponen dan bukan merupakan hasil yang dapat dilihat pada saat itu juga. Pada dasarnya kinerja merupakan sesuatu hal yang bersifat individual, karena setiap karyawan memiliki tingkat kemampuan yang bebeda dalam mengerjakan tugasnya.

Hal ini dibuktikan dengan melihat jawaban responden secara keseluruhan untuk kuesioner variabel kinerja karyawan (Y) diperoleh ratarata score 3.95 dengan kriteria baik. Dari kelima indikator tersebut yang mendapatkan ratting score yang paling rendah adalah pada pernyataan karyawan menetapkan target kerja dengan penuh perhitungan dimana hanya mencapai score 3,72 termasuk dalam kategori baik.

\section{Pengaruh Pelatihan (X1) Terhadap Kinerja Karyawan (Y).}

Berdasarkan hasil statistik, diperoleh nilai koefisien korelasi sebesar 0,664 artinya kedua variabel mempunyai tingkat pengaruh yang kuat. Nilai determinasi atau kontribusi pengaruh pelatihan (X1) terhadap kinerja karyawan $(\mathrm{Y})$ adalah sebesar 0,441 atau sebesar 44,1\% sedangkan sisanya $55,9 \%$ dipengaruhi oleh faktor lain. Hal ini menunjukkan bahwa pelatihan yang meningkat akan meningkatkan kinerja karyawan. Uji hipotesis diperoleh $\mathrm{t}$ hitung $>\mathrm{t}$ tabel atau $(6,152$ $>2,011$ ), hal ini diperkuat dengan probability signicancy $0,000<0,05$, dengan demikian $\mathrm{H} 0$ ditolak dan $\mathrm{H} 1$ diterima artinya terdapat pengaruh positif dan signifikan secara parsial antara pelatihan terhadap kinerja karyawan. Hasil penelitian ini konsisten dengan penelitian.

\section{Pengaruh Disiplin Kerja (X2) Terhadap Kinerja Karyawan (Y) \\ Berdasarkan hasil statistik,} diperoleh nilai koefisien korelasi sebesar 0,685 artinya kedua variabel mempunyai tingkat pengaruh yang kuat. Nilai determinasi atau kontribusi pengaruh disiplin kerja (X2) terhadap kinerja karyawan (Y) adalah sebesar 0,470 atau sebesar $47,0 \%$ sedangkan sisanya $53 \%$ 
dipengaruhi oleh faktor lain. Hal ini menunjukkan bahwa disiplin kerja yang tinggi akan meningkatkan kinerja karyawan. Uji hipotesis diperoleh $\mathrm{t}$ hitung $>\mathrm{t}$ tabel atau $(6,520$ $>2,011)$, hal ini diperkuat dengan probability signicancy $0,000<0,05$, dengan demikian $\mathrm{H} 0$ ditolak dan $\mathrm{H} 2$ diterima artinya terdapat pengaruh positif dan signifikan secara parsial antara disiplin kerja terhadap kinerja karyawan.

\section{Pengaruh Pelatihan (X1) dan Disiplin Kerja (X2) Secara Simultan Terhadap Kinerja Karyawan (Y).}

Berdasarkan hasil penelitian, menunjukkan bahwa pelatihan (X1) dan disiplin kerja (X2) berpengaruh positif terhadap kinerja karyawan dengan diperoleh persamaan regresi $\mathrm{Y}=9,018+0,381 \mathrm{X} 1+0,401 \mathrm{X} 2$. Hasil analisis regresi ini menunjukkan koefisien dari masingmasing variabel bertanda positif, artinya semakin tinggi pelatihan dan disiplin kerja, maka akan semakin tinggi pula kinerja karyawan. Sedangkan nilai korelasi atau tingkat pengaruh antara variabel bebas dengan variabel terikat diperoleh sebesar 0,759 artinya memiliki memiliki pengaruh yang kuat. Nilai dterminasi atau kontribusi pengaruh motivasi dan disiplin kerja sebesar $57,7 \%$ sedangkan sisanya sebesar $42,3 \%$ dipengaruhi oleh faktor lain.

Dari pengujian hipotesis diperoleh $\mathrm{F}$ hitung $>$ Ftabel atau $(32,019>2,800)$, hal tersebut juga diperkuat dengan probability significancy $0,000<0,05$. Dengan demikian $\mathrm{H} 0$ ditolak dan $\mathrm{H} 3$ diterima. Artinya terdapat pengaruh positif dan signifikan secara simultan antara pelatihan dan disiplin kerja terhadap kinerja karyawan.

\section{KESIMPULAN DAN SARAN}

\section{A. Kesimpulan}

Berdasarkan uraian pada bab-bab sebelumnya, dan dari hasil analisis serta pembahasan mengenai pengaruh pelatihan dan disiplin kerja terhadap kinerja karyawan, sebagai berikut :

1. Pelatihan $\left(\mathrm{X}_{1}\right)$ berpengaruh positif dan signifikan terhadap kinerja karyawan (Y) dengan nila korelasi sebesar 0,664 artinya memiliki pengaruh yang kuat dengan koefisien determinasi sebesar 44,1\%. Uji hipotesis diperoleh $\mathrm{t}$ hitung $>\mathrm{t}$ tabel atau $(6,152>2,011)$, hal ini diperkuat dengan probability signifikansi $0,000<$ 0,05, dengan demikian $\mathrm{H}_{0}$ ditolak dan $\mathrm{H}_{1}$ diterima artinya terdapat pengaruh positif dan signifikan antara pelatihan terhadap kinerja karyawan pada PT.Bank Negara Indonesia (BNI) di BSD Tangerang.

2. Disiplin kerja $\left(X_{2}\right)$ berpengaruh positif dan signifikan terhadap kinerja karyawan (Y) dengan nilai korelasi sebesar 0,685 artinya memiliki pengaruh yang kuat dengan koefisien determinasi sebesar 47,0\%. Uji hipotesis diperoleh $\mathrm{t}$ hitung $>\mathrm{t}$ tabel atau $(6,520>2,011)$, hal ini diperkuat dengan probability signifikansi $0,000<$ 0,05 , dengan demikian $\mathrm{H}_{0}$ ditolak dan $\mathrm{H}_{2}$ diterima artinya terdapat pengaruh positif dan signifikan antara disiplin kerja $\left(\mathrm{X}_{2}\right)$ terhadap kinerja karyawan (Y) pada PT. Bank Negara 
Indonesia (BNI) di BSD Tangerang.

3. Pelatihan $\left(X_{1}\right)$ dan disiplin kerja $\left(\mathrm{X}_{2}\right)$ berpengaruh positif dan signifikan terhadap kinerja karyawan (Y) dengan persamaan regresi $\mathrm{Y}=9,018+$ $0,381 X_{1}+0,401 X_{2}$. Nilai korelasi diperoleh sebesar 0,759 artinya variabel bebas dengan variabel terikat memiliki pengaruh yang kuat dengan koefisien determinasi atau pengaruh secara simultan sebesar $57,7 \%$ sedangkan sisanya sebesar $42,3 \%$ dipengaruhi faktor lain. Uji hipotesis diperoleh nilai $F$ hitung $>F_{\text {tabel }}$ atau $(32,019>2,800)$, hal tersebut juga diperkuat dengan probability signifikansi $0,000<0,05$. Dengan demikian $\mathrm{H}_{0}$ ditolak dan $\mathrm{H}_{3}$ diterima. Artinya terdapat pengaruh positif dan signifikan secara simultan antara pelatihan dan disiplin kerja terhadap kinerja karyawan pada PT. Bank Negara Indonesia (BNI) di BSD Tangerang.

\section{B. Saran}

1. Variabel pelatihan pernyataan yang paling lemah adalah pernyataan nomor 3 yaitu daya pikir dan ide karyawan yang baik, sangat dibutuhkan oleh perusahaan dimana hanya mencapai score sebesar 3,80, meskipun termasuk dalam kategori baik namun untuk lebih baik lagi perusahaan harus memperhatikan pengetahuan karyawan, semakin banyak product knowledge yang diketahui maka semakin baik kinerja yang akan mereka berikan untuk perusahaan. Dengan hal itu, maka karyawan akan memberikan sumbangsih yang besar untuk perusahaan dan mempengaruhi keberhasilan serta kemajuan sebuah perusahaan tersebut.

2. Variabel disiplin kerja (X2), pernyataan yang paling lemah adalah pernyataan nomor 2 yaitu karyawan yang bekerja secara efektif dan professional akan menghasilkan pekerjaan yang memuaskan dimana hanya mencapai score sebesar 3,68, meskipun termasuk dalam kategori baik namun untuk lebih baik lagi perusahaan harus lebih konsisten menerapkan aturan yang dibuat sehingga karyawan dapat menunjukkan kesetiaan dan ketaatannya terhadap aturan-aturan yang berlaku bagi sebuah organisasi serta dapat menunjukkan kesetiaan dan ketaatannya terhadap norma-norma yang berlaku bagi sebuah organisasi tersebut.

3. Variabel kinerja karyawan (Y), pernyataan yang paling lemah adalah pernyataan nomor 5 yaitu karyawan menetapkan target kerja dengan penuh perhitungan dimana hanya mencapai score sebesar 3,72, meskipun termasuk dalam kategori baik namun untuk lebih baik lagi perusahaan harus mendorong karyawan untuk dapat mencapai standar kerja atau performa yang baik, menjadikan karyawan sebagai partner dan menghargai 
pendapat mereka atau mengajak mereka berkomunikasi. Pihak manajemen juga harus menunjukkan kepedulian kepada karyawan sehingga mereka termotivasi untuk mencapai kesuksesan serta memberikan reward sebagai faktor pendorong meningkatkan performa.

4. Kontibusi pengaruh (determinasi) antara pelatihan dan disiplin kerja secara simultan terhadap kinerja karyawan sebesar $57,7 \%$, nilai ini masih bisa ditingkatkan dengan secara selektif dapat memprioritaskan pesanan pelanggan yang harus dipenuhi dan kondisi masing-masing variabel bebas harus ditingkatkan secara signifikan. Oleh karenanya disarankan kepada penelitian berikutnya agar melakukan penelitian yang relevan dengan cara memperbaiki indikator yang masih tidak baik atau dengan menambah indikator pertanyaan dan jumlah responden penelitian sehingga akan dapat lebih diketahui variabel yang paling memberikan kontribusi positif bagi perusahaan.

\section{DAFTAR PUSTAKA}

Akhmad Subekhi dan Mohammad Jauhar. 2012."Pengantar Manajemen Sumber Daya Manusia (MSDM)", Cetakan Pertama, Prestasi Pustaka Raya, Jakarta.
As'ad, M. 2014. Psikologi Industri, Seri Umum. "Sumber Daya Manusia". Edisi 4. Liberty, Yogyakarta.

Bambang, Wahyudi. 2012. "Manajemen Sumber Daya Manusia". Bandung: Sulita.

Byars, L. Lloyd and Leslie W. Rue. 2014. "Human Resource Management". 7thedition, New York : McGraw-Hill.

Cascio. 2013. "Manajemen Sumber Daya Manusia". Cetakan Ketujuh. Erlangga. Jakarta.

Danang Sunyoto. 2012. "Dasar-dasar manajemen pemasaran". Cetakan Pertama. Yogyakarta : CAPS.

G.R. Terry. 2011."Manajemen Dasar, Pengertian dan Masalah", edisi revisi, cetakan 1, Penerbit Bumi Aksara. Jakarta.

Hamalik, Oemar. 2008. "Kurikulum dan Pembelajaran". PT. Bumi Aksara. Jakarta.

H.A.R. Tilaar. 2010. Kekuasaan dan Pendidikan : "Kajian Menejemen Pendidikan Nasional dalam Pusaran Kekuasaan”. Jakarta : Rineka Cipta.

Hasibuan, Malayu. S. P. 2013, "Manajemen Sumber Daya Manusia", PT. Bumi Aksara, Jakarta.

. 2011, "Manajemen Sumber Daya Manusia", PT. Bumi Aksara, Jakarta.

Hughes, dkk. 2012. Leadership: "Memperkaya Pelajaran dari Pengalaman". edisi 7. Jakarta : Salemba Humanika.

Lalu, Husni. 2013. "Pengantar Hukum Ketenagakerjaan Indonesia". Edisi Revisi, Jakarta: Rajawali Pers. 
Luthans, Fred. 2016. "Perilaku Organisasi”. (Alih Bahasa V.A Yuwono, dkk), Edisi Bahasa Indonesia, Yogyakarta: ANDI.

Mangkunegara Anwar,Prabu, 2013"Manajemen Sumber Daya Manusia Perusahaan", PT. Remaja Rosdakarya, Bandung

Manulang. 2013."Manajemen Personalia" Cetakan VI, Ghalia Indonesia.

Mathis Robert L. dan Jackson John H. 2016. "Human Resource Management". Alih Bahasa. Salemba Empat. Jakarta.

Mustofa Kamil. 2010. "Model Pendidikan dan Pelatihan (Konsep dan Aplikasi)", Cetakan Pertama, Alfabeta. Bandung.

Rowe, W. Glenn and Guerrero, Laura. 2011. "Cases in Leadership". Second Edition Thousand Oaks-California: SAGE Publications, Inc.

Sadili,Samsudin. 2013. "Manajemen Sumber Daya Manusia". Bandung: Pustaka Setia.

Simamora, Henry. 2014. "Manajemen Sumber Daya Manusia". Cetakan Kedua, STIE YKPN, Yogyakarta.

Siswanto, Bedjo Sastrohadiwiryo. 2011. "Manajemen Tenaga Kerja Indonesia Pendekatan Administratif dan Operasional". Jakarta: Bumi Aksara.

. 2012. "Memahami Penelitian Kualitatif". Bandung : ALFABETA.

Sugiyono. 2011. "Metode Penelitian Kuantitatif, Kualitatif dan R\&D”, Cetakan Ke Tiga Belas, Alfabeta, Bandung.
Sunarsi, D. (2018). Pengaruh Gaya Kepemimpinan, Motivasi Dan Disiplin Kerja Terhadap Kinerja Pendidik Yayasan Marvin. Inovasi, 5(1), 1-18.

Sunarsi, D. (2018). Pengaruh Motivasi Dan Disiplin Terhadap Produktivitas Kerja Karyawan Pada PT. Nadi Suwarna Bumi. Jurnal Semarak, 1(1).

T. Hani,Handoko. 2010. "Manajemen Personalia \& Sumberdaya Manusia”. Edisikedua, BPFE UGM, Yogyakarta. . 2009. "Manajemen Sumber Daya Manusaia", Cetakan IX Jilid I BPFE UGM, Yogyakarta. Thoha, M. (2015). Perilaku Organisasi, Konsep Dasar Aplikasinya. Jakarta: CV. Rajawali. 